\title{
Advanced glycation end products induce chemokine/cytokine production via activation of p38 pathway and inhibit proliferation and migration of bone marrow mesenchymal stem cells
}

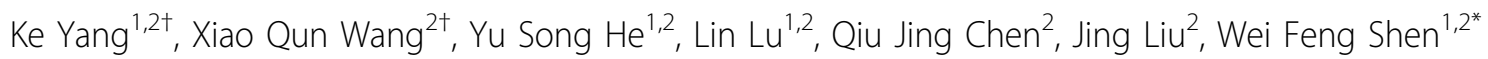

\begin{abstract}
Background: Advanced glycation products (AGEs), as endogenous inflammatory mediator, compromise the physiological function of mesenchymal stem cells (MSCs). MSCs have a potential role in cell replacement therapy in acute myocardial infarction and ischemic cardiomyopathy. However, mechanisms of AGEs on MSCs are still not unveiled.

Methods: Reactive oxygen species (ROS), genes regulation, cell proliferation and migration have been detected by AGE-BSA stimulated MSCs.

Results: We found that in vitro stimulation with AGE-BSA induced generation of reactive oxygen species (ROS), and inhibited dose-dependently proliferation and migration of MSCs. Microarray and molecular biological assessment displayed an increased expression and secretion of $\mathrm{CCl}, \mathrm{CCl}, \mathrm{CCl} 4$ and $\mathrm{II} 1 \mathrm{~b}$ in a dose- and time-dependent manner. These chemokines/cytokines of equivalent concentration to those in conditioned medium exerted an inhibitory effect on MSC proliferation and migration after stimulation for $24 \mathrm{~h}$. Transient elevation of phospho-p38 in MSCs upon AGE-BSA stimulation was blocked with p38 inhibitor.

Conclusions: The study indicates that AGE-BSA induces production of chemokines/cytokines in a dose- and timedependent manner via activation of ROS-p38 mediated pathway. These chemokines/cytokines exert an inhibitory effect on MSC growth and migration, suggesting an amplified dysfunction of MSCs by AGEs.
\end{abstract}

\section{Background}

Emerging evidence has demonstrated that cell-based therapy including mesenchymal stem cells (MSCs) for acute myocardial infarction or ischemic cardiomyopathy holds promise [1-3]. MSCs, isolated from bone marrow, exhibit a high capacity of ex vivo expansion, allowing further biological modifications and clinically huge-dose preparation of the cells. Besides, MSCs are characterized by great potential to transdifferentiate into cardiomyocytes and vascular-like structure [4-6].

\footnotetext{
* Correspondence: rjshenweifeng@yahoo.com.cn

† Contributed equally

'Department of Cardiology, Ruijin Hospital, Jiaotong University School of

Medicine, Shanghai 200025, P.R. China

Full list of author information is available at the end of the article
}

Diabetes is associated with adverse outcome after myocardial infarction [7]. Not unexpectedly, the effects of improving left ventricular function and reducing infarct size after stem cell therapy, which are observed in non-diabetes, have been significantly attenuated or bleached in diabetic patients with acute myocardial infarction [8]. Type 2 diabetes mellitus (T2DM) not only decreases the abundance of bone marrow derived CD133+ stem cells following acute myocardial infarction, but also limits their activation [9]. However, the abnormal profiles of MSCs in diabetes and diseaserelated mechanisms have been less clarified.

One of the reasons for stem cell dysfunction is due to exposure of advanced glycation end products (AGEs) in 
diabetic milieu. Previous studies have shown that AGEs are significantly associated with diabetic cardiovascular complications and worse prognosis $[10,11]$. In vitro stimulation with glyceraldehydes- or glycolaldehydemodified albumin reduces proliferation of MSCs, and increases intracellular generation of reactive oxygen species (ROS) and number of apoptotic cells, with accompanying inhibition of adipogenic or chondrogenic differentiation [12]. It remains unclear if glycated protein could amplify the inflammatory response in MSCs and inhibit proliferation and migration of these cells.

The present study has shown that AGE-BSA dosedependently inhibited proliferation and migration of MSCs via ROS-p38 MAPK-mediated pathway. Microarray analysis and molecular biological approach of gene expressions displayed increased expression and secretion of chemokines and cytokines including $\mathrm{CC}$ chemokine ligand (Ccl) 2, Ccl3, Ccl4 and interleukin (Il)-1 beta. Notably, these proinflammatory factors of equivalent concentration to those in conditioned medium (AGE-BSA, $200 \mathrm{ug} / \mathrm{ml}$ ) functioned to inhibit proliferation and migration of MSCs.

\section{Materials and methods}

The Animal Care Committee of the National Cardiovascular Center approved the experimental protocol.

\section{Cell culture}

Isolation and expansion of MSCs were performed as previously described [13]. Briefly, bone marrow cells were isolated from male Sprague Dawley rats (weighing 100$150 \mathrm{~g}$ ) by flushing out the femoral and tibial cavities with phosphate-buffered saline. Cells were grown in low glucose Dulbecco's Modified Eagle Medium, supplemented with $10 \%$ fetal bovine serum, $100 \mathrm{U} / \mathrm{ml}$ penicillin and 100 $\mathrm{ug} / \mathrm{ml}$ streptomycin (Gibco, NY, USA). These cells were proved to be positive for CD29 (Biolegend, CA, USA) and CD90 (eBioscience, CA, USA) surface markers and negative for CD34 (Santa cruz, CA, USA) and CD45 (Abcam, Cambridge, UK) [14]. The STEMPRO osteogenesis and adipogenesis differentiation kits (Gibco) were used to detect the capacity of MSC differentiation.

\section{MTT assay}

The proliferation of MSCs was tested by 3-(4, 5dimethylthiazol-2-yl)-2, 5-diphenyltetrazolium bromide (MTT, Sigma-Aldrich, Mo, USA) [15]. MSCs $\left(1 \times 10^{4} /\right.$ well) were plated on a 96-well plate and stimulated by different factors at varying doses and time points. OD was measured by Microplate Reader (Bio-Rad, CA, USA) at $490 \mathrm{~nm}(\mathrm{n}=3)$.

\section{Measurement of intracellular ROS generation}

Intracellular formation of ROS was evaluated using a fluorescent probe $\mathrm{CM}-\mathrm{H}_{2}$ DCFDA (Invitrogen, CA, USA) as previously described [16]. Briefly, cells were seeded in a 6-well plate $\left(2 \times 10^{5}\right.$ cells/well $)$, and incubated with 10 uM CM- $\mathrm{H}_{2}$ DCFDA for $60 \mathrm{~min}$ at $37^{\circ} \mathrm{C}$. Cell nucleus was labeled by Hoechst 33342 (Sigma-Aldrich), and images were then taken (Olympus, Tokyo, Japan). The ROS fluorescence intensity was analyzed using Flow cytometry (BD, NJ, USA) $(n=3)$.

\section{Wound healing}

Wound healing assay was performed as previously described [17]. Briefly, MSCs were grown to confluence in $60-\mathrm{mm}^{2}$ dishes and starved for $24 \mathrm{~h}$. After completion of a linear wound, medium was changed to fresh DMEM with or without addition of factors. At 0 and 24 $\mathrm{h}$, images were taken (Olympus). The area of each dish was measured using IMAGE-PRO PLUS Version 6.2 (Media Cybernetics, MD, USA).

\section{Boyden chamber assay}

Chemotaxis was measured using a 48-well Transwell plate (Millipore, MA, USA). MSCs at $60-70 \%$ confluence were starved overnight in serum-free DMEM, trypsinized, and resuspended in serum-free DMEM $\left(3 \times 10^{4}\right.$ cells/300 ul). The cell suspension was added to the upper chamber, and the bottom chamber was filled with DMEM with $10 \%$ FBS or serum-free medium. The chamber was incubated at $37^{\circ} \mathrm{C}$ in a $\mathrm{CO}_{2}$ incubator for $5 \mathrm{~h}$, then the filter was removed and nonmigrated cells were scraped from the upper surface. The migrated cells were stained and treated with lysis buffer, and number of cells was then quantified by OD $560 \mathrm{~nm}$ measurement.

\section{Microarray analysis of gene expression}

MSCs $\left(5 \times 10^{5}\right)$ were plated on 6 -cm dishes and cultured with AGE-BSA (200 ug/ml) (Calbiochem, Darmstadt, Germany) for 12 and $24 \mathrm{~h}$. Total RNA was extracted from cells using an RNeasy Mini kit (Qiagen, Hilden, Germany). Then, 10 ug of total RNA was reverse-transcribed to produce biotin-labeled cRNA, with GeneChip One-Cycle Target Labeling and Control Reagents (Affymetrix, CA, USA). After fragmentation, 10 ug of cRNA was hybridized with GeneChip Rat Genome 230 2.0 Array. GeneChips were then scanned using a GeneChip Scanner 3000. Normalization, filtering, and gene ontology analysis were performed with GeneSpring GX 7.3.1 software (Agilent Technologies, CA, USA).

The detected signals were assessed by gene hierarchical clustering of logarithmic values at each time point, and then displayed in a heatmap. Clustering was performed using Cluster 3.0 and the patterns were created and viewed using Java TreeView 1.0.13 software. Raw data from each array were analyzed using Mul-Class Dif [18-20]. Gene coexpression networks based upon 
normalized signal intensity were built to find interactions among genes [21]. Moreover, for assessing certain properties of the networks, k-cores in graph theory was introduced as a method of simplifying graph topology analysis [22,23].

\section{Quantitative real-time RT-PCR}

Total RNA was extracted as described above. Briefly, 5 ug of total RNA was reverse-transcribed into cDNA using a reverse transcription system (Promega, WI, USA). PCR amplification was performed with Power SYBR Green PCR Master Mix (Applied BioSystems, CA, USA) in a StepOne (Applied BioSystems). The oligonucleotides used in quantitative real-time RT-PCR analysis are listed in Table 1. Gene expression levels were normalized with beta-actin, and data were analyzed with StepOne software v2.1 (Applied BioSystems).

\section{Measurement of chemokines/cytokines in conditioned medium}

The supernatant of MSCs was collected after stimulationôand levels of $\mathrm{Ccl} 2, \mathrm{Ccl} 3, \mathrm{Ccl} 4$ and Il1b were measured using commercially available ELISA kits of $\mathrm{Ccl} 2$, Il1b(all for Invitrogen), Ccl3 (ABD Serotec, NC, USA) and Ccl4 (eBioscience).

\section{Effect of chemokines/cytokines on MSCs}

Since the distinct effects of $\mathrm{Ccl} 2, \mathrm{Ccl} 3, \mathrm{Ccl} 4$ and Il1b (all for Invitrogen) on MSCs might be disturbed using conditioned medium, MSCs were therefore stimulated by commercially available chemokines/cytokines with equivalent concentration at low and high doses (as physiological or disease status [24-29]). Proliferation and migration were evaluated by MTT and wound healing assays.

\section{Western blot}

Cells were lysed with the ProteoJET Mammalian Cell Lysis Reagent (Fermentas, MD, USA) to extract cytoplamic proteins. Equal amounts of protein extracts were subjected to $12 \%$ SDS/PAGE and blotted onto a poly (vinylidene difluoride) membrane. The membrane was blocked and probed overnight at $4{ }^{\circ} \mathrm{C}$ with antibodies against total or phosphorylated p38 (Cell Signaling Technology, MA, USA), followed by incubation with horseradish peroxidase-conjugated secondary antibodies for $1 \mathrm{~h}$ at room temperature. Blots were developed using an ECL detection system (Millipore, MA, USA). Each image was captured and the intensity of each band was analyzed with Quantity One (Bio-Rad).

\section{AGE-BSA stimulation and p38 inhibition}

MSCs were seeded on 96- or 6-well culture plates for MTT, microarray assay, ROS measurement, cytokine/ chemokine detection, RT-PCR or western blot analysis. Cells were incubated with AGE-BSA (Calbiochem) at varying concentrations and up to different time points.

To probe the effect of P38 inhibition on activation of AGE-BSA stimulated cells, MSCs were pretreated with SB203580 (20 uM) (Merck, Darmstadt, Germany) $1 \mathrm{~h}$ before AGE-BSA stimulation. The concentration of inhibitor used was based upon dose-response experiments (data not shown), with the maximal inhibitory effect. For each experiment, cell viability was always more than $90 \%$. Cell-free supernatants were collected and stored at $-80^{\circ} \mathrm{C}$ until analysis.

\section{Statistical analysis}

All values are expressed as mean \pm SD. Student's paired $t$ test was performed for comparison of paired samples, and ANOVA was used for multiple group comparisons, followed by Friedman's posttest. A probability (p) value $<0.05$ was considered significant.

\section{Results}

\section{AGE-BSA induced ROS accumulation and attenuated} proliferation of MSCs

Fluorescence-activated cell sorting (FACS) showed that MSCs were negative for CD34 and CD45, and strongly expressed CD29 and CD90. When cultured in adipogenic or osteogenic medium, MSCs were differentiated into adipocytes or osteoblasts (see Additional File 1; Figure S1). The MTT assay showed that AGE-BSA timeand dose-dependently inhibited proliferation of MSCs, with concentration of $200 \mathrm{ug} / \mathrm{ml}$ exhibiting remarkable effects at $24 \mathrm{~h}(\mathrm{p}<0.05$, Figure 1A). AGE-BSA regulated RAGE expression (Figure 1B). After stimulation with AGE-BSA $(200 \mathrm{ug} / \mathrm{ml})$ at 12 or $24 \mathrm{~h}$, profuse ROS generation was observed in MSCs (both $\mathrm{p}<0.05$ ) (Figure $1 \mathrm{C}$ and Figure 1D).

Table 1 Primers used in real-time PCR

\begin{tabular}{ccll}
\hline Gene Name & Product size $\mathbf{( b p )}$ & Sense primer & Anti-sense primer \\
\hline$\beta$-actin & 176 & CGTGACATCCGTAAAGACC & TAGAGCCACCAATCCACACA \\
Ccl2 & 280 & AATGAGTCGGCTGGAGAA & GCTTGAGGTGGTTGTGGA \\
Ccl3 & 155 & GCTGCCCTTGCTGTTCTT & CAAAGGCTGCTGGTCTCA \\
Ccl4 & 148 & TCTCCTCCTGCTTGTGGC & GCAAAGGCTGCTGGTCTC \\
$\| 1-\beta$ & 190 & GGATGGTGGAGCAAGGG & GCACTGCTTCCCAGGCTT \\
\hline
\end{tabular}



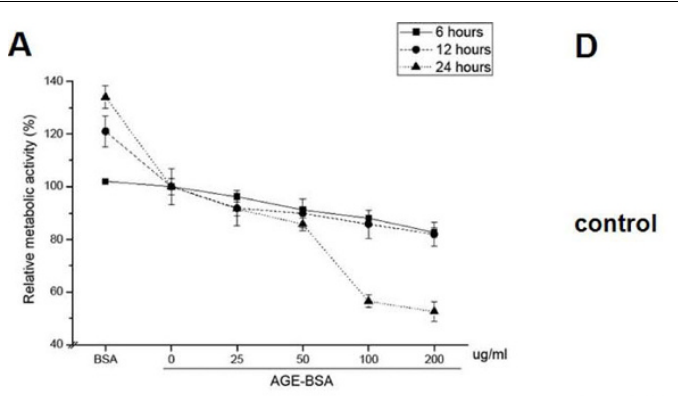

B

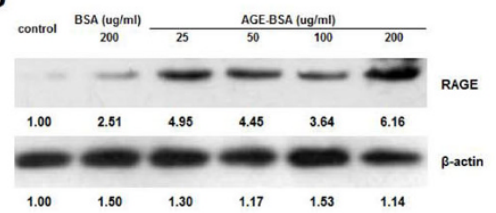

AGE-BSA

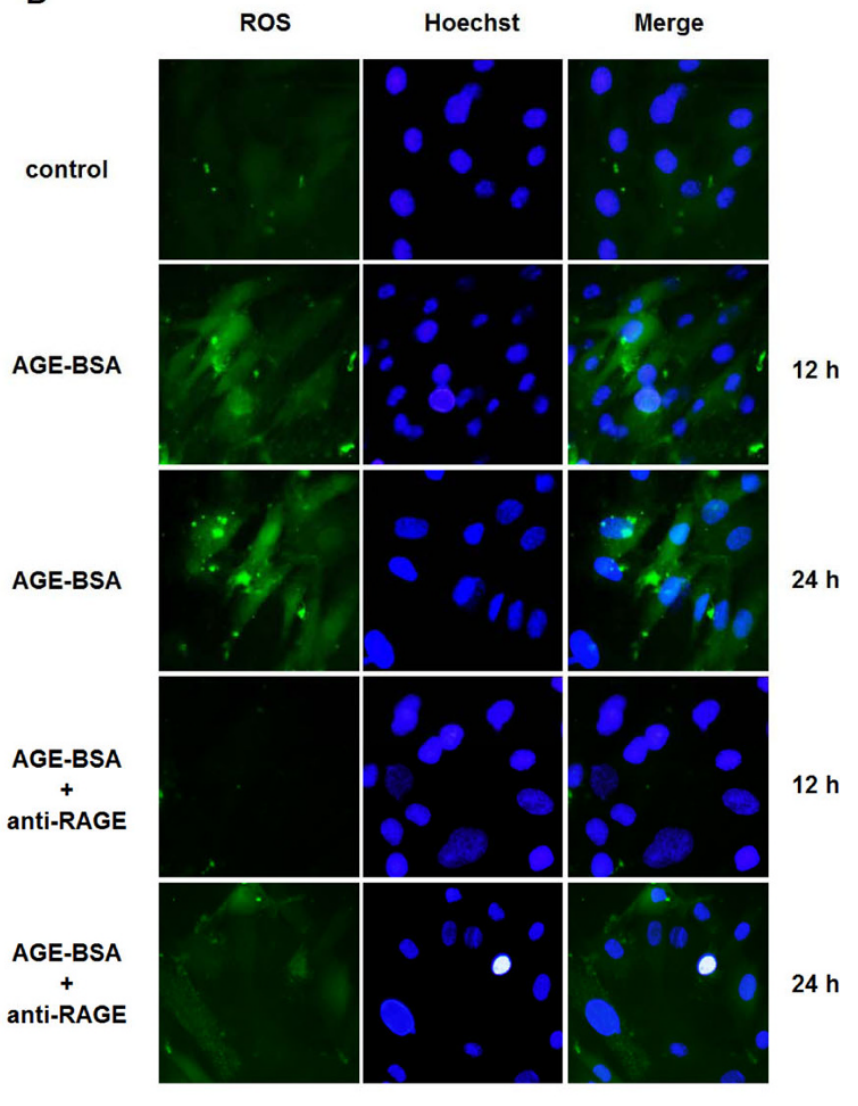

AGE-BSA

C
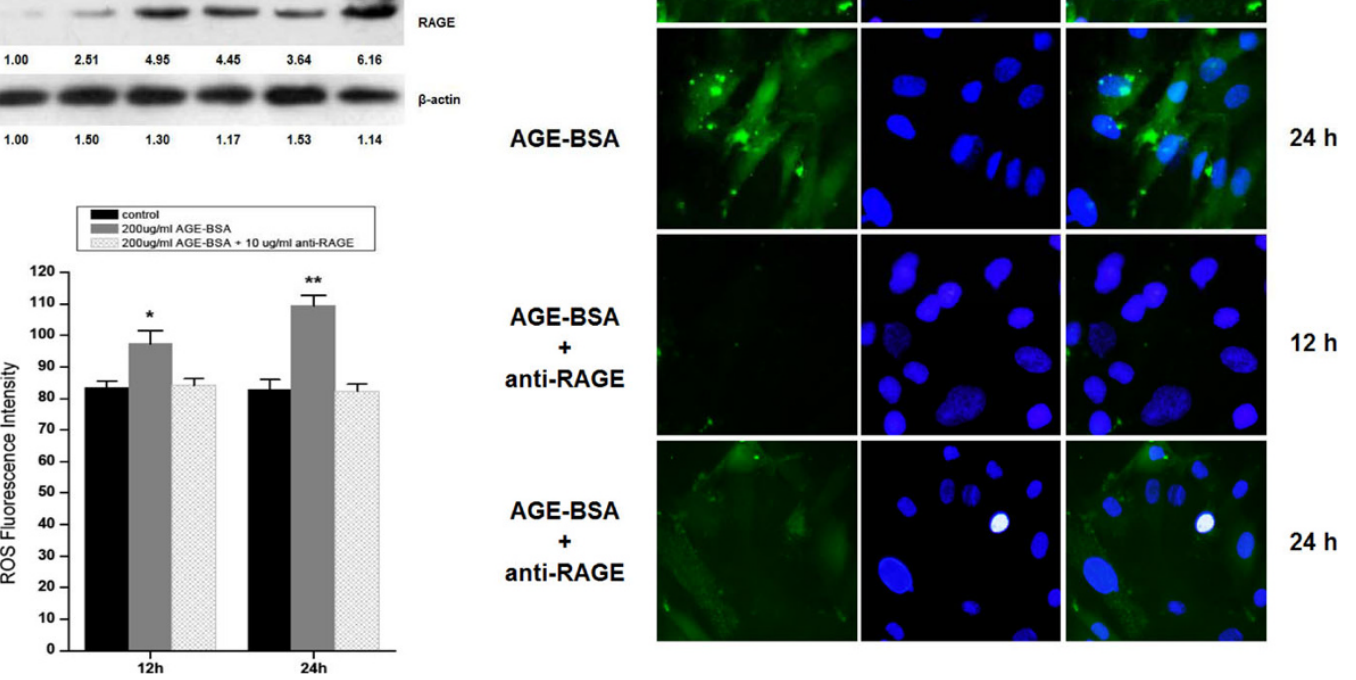

Figure 1 Effects of AGE-BSA stimulation on MSC proliferation and ROS production. (A) MSCs were stimulated by AGE-BSA and BSA (as negative control) for MTT testing (mean $\pm S D, n=3$ ). (B) AGE-BSA treated MSCs, and RAGE has been detected. (C) MSCs stimulated by AGE-BSA for 12 and $24 \mathrm{~h}$ were labeled with CM-H2DCFDA. ROS fluorescence intensity was analyzed using flow cytometry (mean $\pm S D, n=3$; ${ }^{* P}<0.05$, ${ }^{* *} \mathrm{P}<0.01$ vs. control). (D) MSCs were labeled with CM-H2DCFDA and Hoechst 33342. Images were taken with different fluorescence wavelengths (200x).

\section{AGE-BSA attenuated migration of MSCs}

Wound healing assay revealed that AGE-BSA produced a concentration-dependent decrease in migration of MSCs (Figure 2A and 2B). Similarly, AGE-BSA at these concentrations obviously inhibited transwell migration (all $\mathrm{p}<0.05$ ) (Figure 2C and 2D).

\section{Gene expression regulated by AGE-BSA}

The genes with significant change $(\mathrm{p}<0.05$ and FDR $<$ 0.05 ) were selected (Table 2). Cluster analysis was shown in Figure 3A. Coexpression network of AGEsinduced genes was built (Figure 3B), in which Ccl2, $\mathrm{Ccl} 3, \mathrm{Ccl} 4$ and Il1b were located centrally.

Microarray assay revealed an elevated expression of $\mathrm{Ccl} 2, \mathrm{Ccl} 3, \mathrm{Ccl} 4$ and $\mathrm{Il1b}$ after induction of AGEs. Real-time PCR verified a time- and dose-dependent increase of these chemokines/cytokines after incubation with AGE-BSA (Figure 3C and Figure 3D). As expected, the levels of $\mathrm{Ccl} 2, \mathrm{Ccl} 3, \mathrm{Ccl} 4$ and $\mathrm{Il} 1 \mathrm{~b}$ displayed a time- and dose- dependent increase $(n=3$, $\mathrm{p}<0.01$ ) (Figure 3E and 3F).

\section{Activity of p38 pathway and chemokines/cytokines}

MAP kinases including p38, ERK $1 / 2$ and JNK showed (see Additional File 2; Figure S2) that only p38 pathway affected proliferation and migration of MSCs. Stimulation with AGE-BSA (200 ug/ml) resulted in increased phosphorylation of p38 at 20, 30 and 50 min (Figure 4A). In contrast, blockage of p38 by SB203580 significantly attenuated effects of AGE-BSA on proliferation, migration and chemokine/cytokine secretion of MSCs (Figure 4B, 4C and 4D). Notably, a time- and dose-dependent inhibition of cell proliferation and migration were induced by $\mathrm{Ccl} 2, \mathrm{Ccl} 3, \mathrm{Ccl} 4$ and Il1b (Figure 4E and 4F)

\section{Discussion}

The present study demonstrates that AGE-BSA inhibits proliferation and migration of MSCs, and induces 


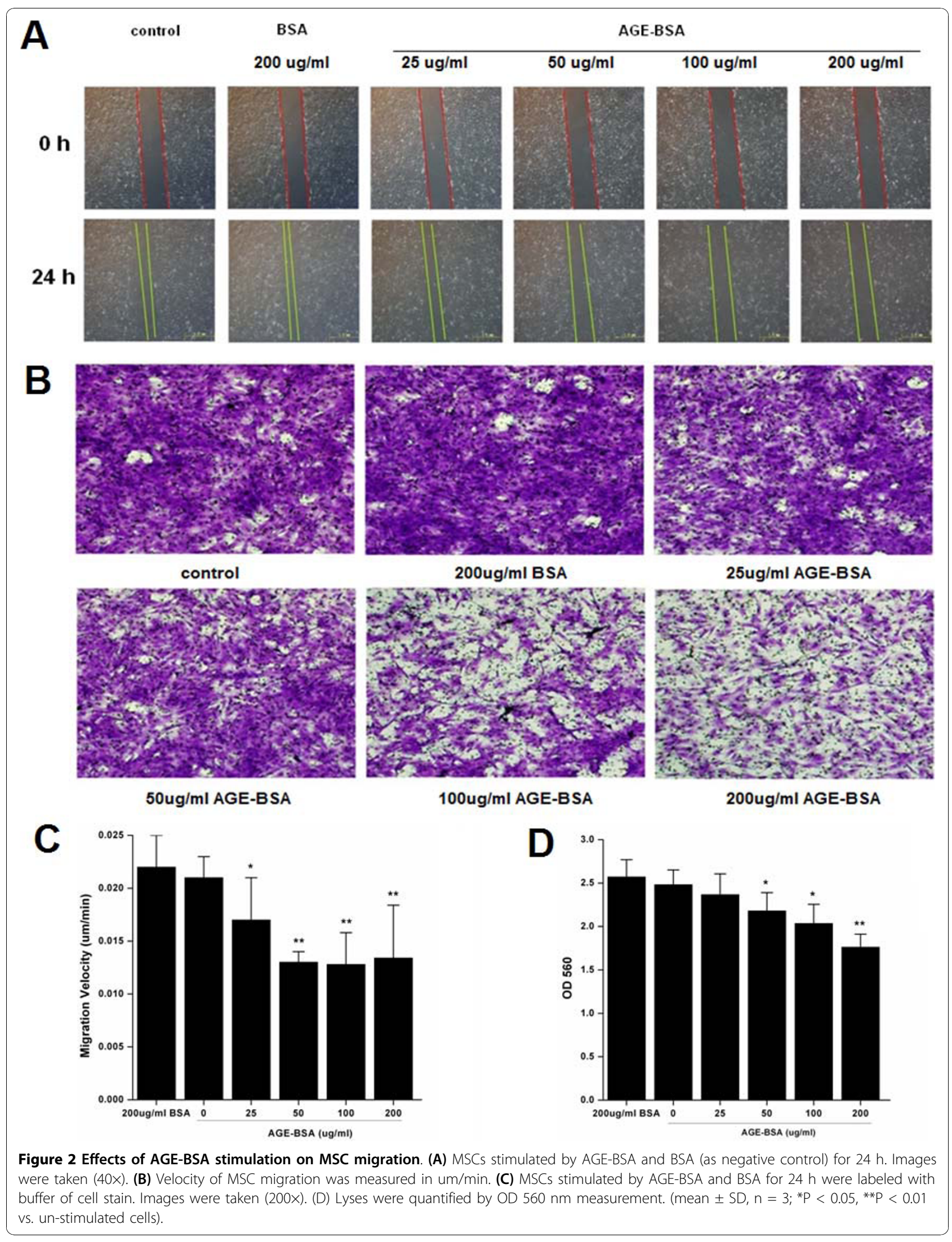


Table 2 Multi-class differentiation analysis of genes

\begin{tabular}{|c|c|c|c|}
\hline Description & Gene symbol & p-value & FDR \\
\hline EGF-like module containing, mucin-like, hormone receptor-like 1 & Emr1 & 7.00E-07 & 0.0003 \\
\hline Chemokine (C-C motif) ligand 3 & $\mathrm{Ccl} 3$ & 1.00E-06 & 0.0003 \\
\hline Chemokine (C-C motif) ligand 2 & $\mathrm{Ccl} 2$ & $1.04 \mathrm{E}-05$ & 0.0022 \\
\hline Interleukin $1 \beta$ & $\| 1 \mathrm{~b}$ & 2.27E-05 & 0.0032 \\
\hline Chemokine (C-C motif) ligand 4 & $\mathrm{Ccl} 4$ & $2.43 \mathrm{E}-05$ & 0.0032 \\
\hline Transferrin receptor & Tre & $3.18 \mathrm{E}-05$ & 0.0034 \\
\hline Integrin alpha L & Itgal & 0.0003331 & 0.0309 \\
\hline $\mathrm{NAD}(\mathrm{P}) \mathrm{H}$ dehydrogenase, quinone 1 & Nqo1 & 0.000419 & 0.0340 \\
\hline Fatty acid binding protein 3 , muscle and heart & Fabp3 & 0.0004791 & 0.0341 \\
\hline Nuclear factor of kappa light polypeptide gene enhancer in B-cells inhibitor, alpha & Nfkbia & 0.000525 & 0.0341 \\
\hline Transferrin receptor & Tfre & 0.0007492 & 0.0442 \\
\hline Nuclear factor of kappa light polypeptide gene enhancer in B-cells inhibitor, epsilon & Nfkbie & 0.0010249 & 0.0512 \\
\hline Glutathione S-transferase A2 & Gsta2 & 0.0010941 & 0.0512 \\
\hline Interferon induced transmembrane protein 1 & Ifitm1 & 0.0011035 & 0.0512 \\
\hline Fc fragment of IgE, high affinity I, receptor for; gamma polypeptide & Fcer1g & 0.0015853 & 0.0686 \\
\hline Fc receptor-like S, scavenger receptor & Fcrls & 0.0027302 & 0.1107 \\
\hline Synaptic vesicle glycoprotein $2 \mathrm{~b}$ & Sv2b & 0.003675 & 0.1403 \\
\hline Doublesex and mab-3 related transcription factor 2 & Dmrt2 & 0.0078799 & 0.2841 \\
\hline Matrix metallopeptidase 12 & Mmp12 & 0.0091006 & 0.3109 \\
\hline Stearoyl-Coenzyme A desaturase 1 & Scd1 & 0.0101781 & 0.3303 \\
\hline Runt-related transcription factor 1; translocated to, 1 (cyclin D-related) & Runx1t1 & 0.0138214 & 0.4254 \\
\hline Allograft inflammatory factor 1 & Aif1 & 0.0144188 & 0.4254 \\
\hline Rho GTPase activating protein 5 & Arhgap5 & 0.0162094 & 0.4574 \\
\hline F-box protein 5 & $\mathrm{Fbxo5}$ & 0.0174488 & 0.4718 \\
\hline Zinc finger protein 367 & Zfp367 & 0.0237975 & 0.6178 \\
\hline Origin recognition complex, subunit 6 like (yeast) & Orc6l & 0.0252814 & 0.6311 \\
\hline A kinase (PRKA) anchor protein 12 & Akap12 & 0.0334329 & 0.7749 \\
\hline Family with sequence similarity $122 \mathrm{~B}$ & Fam122b & 0.0361249 & 0.8085 \\
\hline Solute carrier family 6 (neurotransmitter transporter, taurine), member 6 & Slc6a6 & 0.0465527 & 0.8886 \\
\hline
\end{tabular}

production of chemokines/cytokines in a dose- and time-dependent manner via activation of ROS-p38 mediated pathway. Furthermore, these chemokines/cytokines exert an inhibitory effect on MSCs growth and migration, suggesting an amplified dysfunction of MSCs by AGEs stimulation.

Interaction of AGEs and receptor for AGEs (RAGE) relays cell surface signals to various intracellular pathways including p38, JNK/STAT and other mitogenactivated protein kinases. Activation of p38 pathway is responsible for a myriad of transcriptional programs leading to enhance expression of pro-inflammatory cytokines [24-26]. Over-production of intracellular ROS results in inflammatory activation and impairment of physiological function $[27,28]$, and constitutes a key element in diabetic pathophysiology. In this study, we observed an increased ROS production and elevated p38 phosphorylation in MSCs by AGE-BSA stimulation, accompanying with reduced proliferation and migration and increased pro-inflammatory cytokine/chemokine production in MSCs. The extent of MSC abnormalities was closely related to the dose of AGEs, whereas blockage of p38 reverses these pathological changes. Collectively, our results suggest that AGEs cause abnormal growth and migration of MSCs, and trigger production of pro-inflammatory factors via generation of ROS and activation of p38 pathway.

Recently study demonstrated that p38 pathway activation has been associated with interleukin-6 (IL-6), cyclooxygenase-2 (COX-2) and CCL2 expression increased in the heart. The long-term activation of p38 also regulated post-infarct cardiac remodeling in type 2 diabetes. Glucagon-like peptide- 1 is an incretin hormone that effects on glucose metabolism and may involve activation of p70s6 kinase, ERK1/2, and p38 MAPK. All of these research indicated that p38 involved in coronary heart disease [29-31].

In this study, a dose- and time-dependent over-expression of $\mathrm{Ccl} 2, \mathrm{Ccl} 3, \mathrm{Ccl} 4$ and Il1b in MSCs by AGE-BSA stimulation was evident. Previous studies have demonstrated that in vivo levels of these pro-inflammatory chemokines/cytokines are significantly associated with type 
B
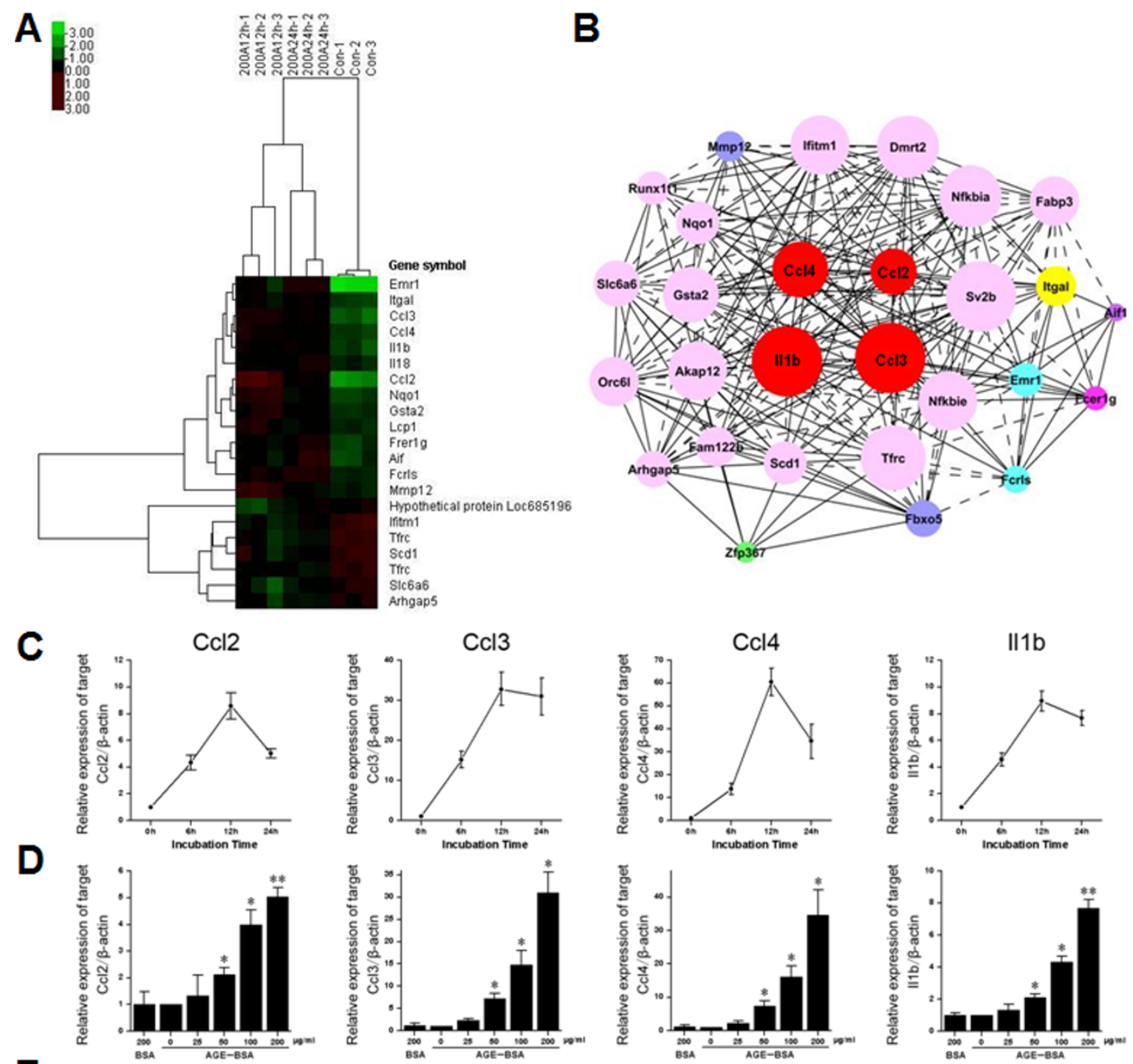

E
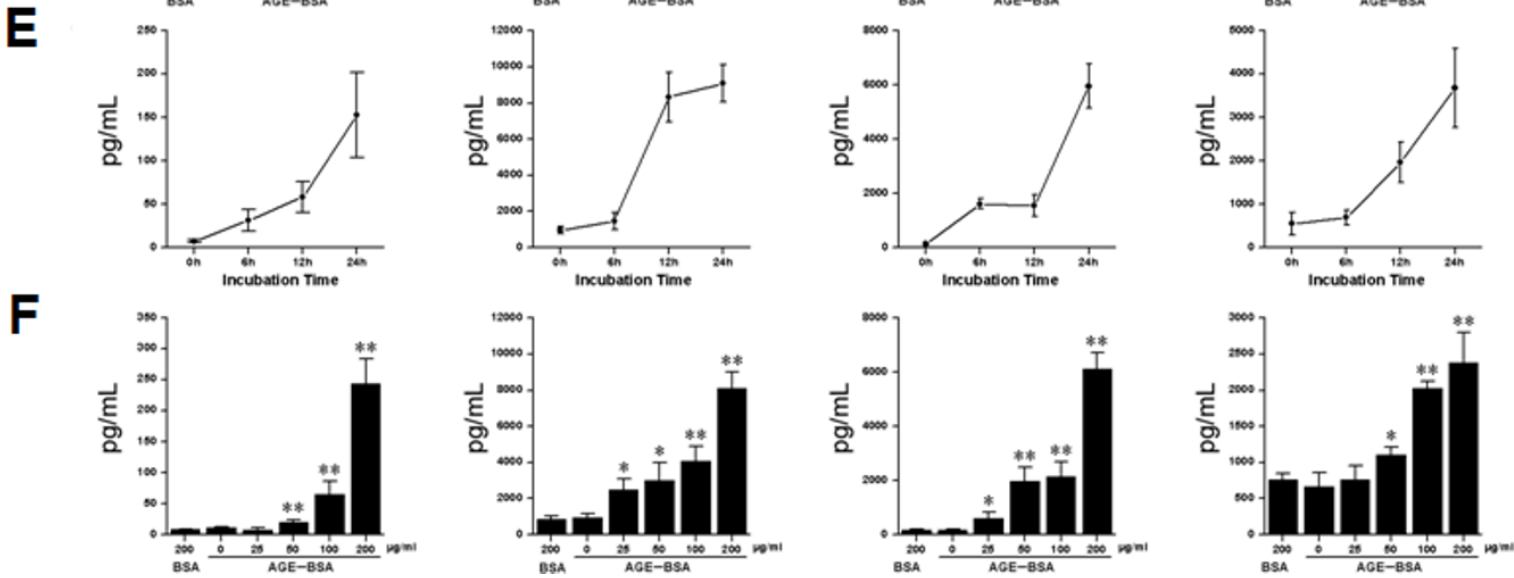

Figure 3 Gene expression regulated by AGE-BSA. (A) $\mathrm{Ccl}$, $C \mathrm{Cl} 3, \mathrm{Ccl} 4$ and $\| 1 \mathrm{~b}$ showed significant difference $(\mathrm{p}<0.01)$ in MSCS stimulated by AGE-BSA for 12 and $24 \mathrm{~h}$ using Cluster 3.0 software. (B) k-core of gene expression was analyzed by GeneRelNet, and net of gene co-expression was drawn. (C) Time- and (D) dose-dependent expression of chemokines/cytokines stimulated by AGE-BSA. $\beta$-actin was used to normalize the results. (E) Time- and (F) dose-dependent chemokine/cytokine production stimulated by AGE-BSA (mean $\pm \mathrm{SD}, \mathrm{n}=3 ;{ }^{*} \mathrm{P}<0.05$, **P $<0.01$ vS. un-stimulated cells). (mean $\pm S D, n=3 ;{ }^{*} P<0.05,{ }^{* * P}<0.01$ vs. un-stimulated cells). 


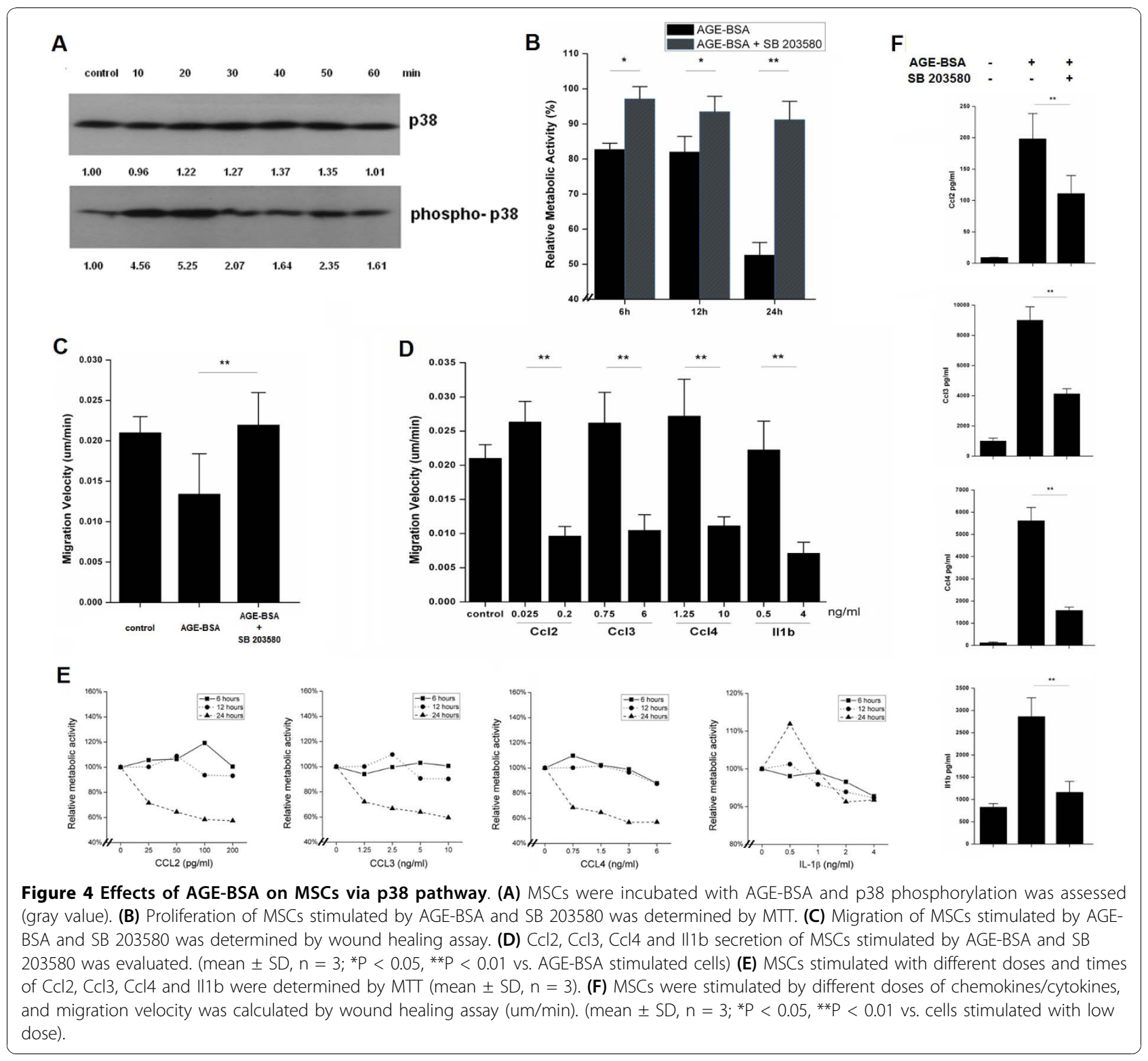

1 and type 2 diabetes, diabetic complications, and clinical outcomes [32-40]. Consistent with previous findings, our study further showed that chemokines/cytokines of concentration equivalent to those in conditioned medium exerted an inhibitory effect on MSC growth and migration. Notably, the concentrations of these proinflammatory factors in this experiment were also similar to in vivo levels in diabetic patients $[[33,35,36]$ and [39]]. Thus, autocrine-released chemokines/cytokines from MSCs by AGEs stimulation and those from other sources jointly contributed to impairment of cellular function.

Based upon these observations, we hypothesized that migrated or transplanted MSCs may be functionally dysregulated in diabetic, hypoxic and inflammatory environment and exhibit low growth rate and impaired function. Inflammation is intensified with significant release of pro-inflammatory chemokines/cytokines from MSCs. These factors, with diabetic milieu, in return further damage cellular function, which mitigate the therapeutic effects of MSCs in diabetes. Interestingly, mildly elevated levels of $\mathrm{Ccl} 2, \mathrm{Ccl} 3, \mathrm{Ccl} 4$ and Il1b stimulated MSC homing and promote repairing of the damage tissues in non-diabetic physiological conditions [41-46].

\section{Conclusions}

The present study demonstrates an inhibitory effect of AGEs on MSC proliferation and migration via ROS- p38mediated pathway and production of pro-inflammatory 
chemokines/cytokines. Measures used for glycemic control and anti-inflammation should be emphasized especially in patients with diabetes undergoing cell therapy with MSCs.

\section{List of abbreviations}

MSCs: mesenchymal stem cells; AGEs: advanced glycation end products; T2DM: Type 2 diabetes mellitus; ROS: reactive oxygen species; Ccl2: chemokine ( $\mathrm{C}-\mathrm{C}$ motif) ligand 2; Ccl3: chemokine (C-C motif) ligand 3; Ccl4: chemokine (C-C motif) ligand 4; I1 b: interleukin 1 beta; MTT: 3- (4, 5dimethylthiazol- 2- yl)- 2, 5-diphenyltetrazolium bromide; RT-PCR: reverse transcription polymerase chain reaction; FACS: Fluorescence-activated cell sorting; FDR: False discovery rate; RAGE: advanced glycosylation end product-specific receptor; SB203580, 4-(4-fluorophenyl)-2-(4methylsulfinylphenyl)-5-(4- pyridyl) imidazole.

\section{Additional material}

\section{Additional File 1: Fig. S1 Characterization of isolated MSCs. (A)} STEMPRO Osteogenesis differentiation medium induced MSC osteogenesis, stained by alkaline phosphatase. STEMPRO Adipogenesis differentiation medium induced MSC adipogenesis, stained by oil red $\mathrm{O}$. The entire image was taken (10x). (B) Flow cytometry shows the passage 3 MSCs were negative for reactivity to antigens CD45 and CD34, and positive for reactivity to antigens CD90 and CD29.

Additional File 2: Fig. S2 Effect of other MAPK pathway stimulated by AGE-BSA. (A) ERK1/2 and JNK phosphorylation of MSCs incubated with AGE-BSA (200 ug/ml for 0, 10, 20, 30, 40, 50 and $60 \mathrm{~min}$ ) was determined (gray value). (B) Proliferation of MSCs incubated with AGEBSA (200 ug/ml) and PD 98059 (20 uM) or JNK inhibitor II (10 nM) for 0, 12 and $24 \mathrm{~h}$ was assessed by MTT. (C) Migration of MSCs incubated with AGE-BSA (200 ug/ml) and PD 98059 (20 uM) or JNK inhibitor II (10 nM) for $24 \mathrm{~h}$ was determined by wound healing assay. (mean $\pm S D, n=3$; $P$ â 0.05 vs. AGE-BSA stimulated cells).

\section{Acknowledgements}

This work was supported by grants from Nature Science Foundation of China (30871084) and Postdoctoral Science Foundation of China (20090460631). We thank GMINIX Informatics Ltd., Co for their technical assistance in bioinformatics analysis.

\section{Author details}

'Department of Cardiology, Ruijin Hospital, Jiaotong University School of Medicine, Shanghai 200025, P.R. China. ${ }^{2}$ Institute of Cardiovascular Diseases, Jiaotong University School of Medicine, Shanghai 200025, P.R. China.

\section{Authors' contributions}

$\mathrm{KY}$ and $\mathrm{XW}$ carried out the molecular research, participated in cell biology experiment and drafted the manuscript. YH carried out the microarray test, participated in cell biology experiment. QC and $J$ carried out immunoassays, participated in molecular research. KY, XW, YH and LL participated in the design of the study and performed the statistical analysis. WS conceived of the study, and participated in its design and coordination. All authors read and approved the final manuscript.

\section{Competing interests}

The authors declare that they have no competing interests.

Received: 25 September 2010 Accepted: 22 October 2010 Published: 22 October 2010

\section{References}

1. Martin-Rendon E, Brunskill SJ, Hyde CJ, Stanworth SJ, Mathur A, Watt SM: Autologous bone marrow stem cells to treat acute myocardial infarction: a systematic review. Eur Heart J 2008, 29:1807-1818.
2. Rosenzweig A: Cardiac cell therapy-mixed results from mixed cells. $N$ Engl I Med 2006, 355:12.

3. Chen SL, Fang WW, Ye F, Liu YH, Qian J, Shan SJ, Zhang JJ, Chunhua RZ, Liao LM, Lin S, Sun JP: Effect on left ventricular function of intracoronary transplantation of autologous bone marrow mesenchymal stem cell in patients with acute myocardial infarction. Am J Cardiol 2004, 94:92-95.

4. Shake JG, Gruber PJ, Baumgartner WA, Senechal G, Meyers J, Redmond JM, Pittenger MF, Martin BJ: Mesenchymal stem cell implantation in a swine myocardial infarction model: engraftment and functional effects. Ann Thorac Surg 2002, 73:1919-1926.

5. Toma C, Pittenger MF, Cahill KS, Byrne BJ, Kessler PD: Human mesenchymal stem cells differentiate to a cardiomyocyte phenotype in the adult murine heart. Circulation 2002, 105:93-98.

6. Thompson CA, Nasseri BA, Makower J, Houser S, McGarry M, Lamson T, Pomerantseva I, Chang JY, Gold HK, Vacanti JP, Oesterle SN: Percutaneous transvenous cellular cardiomyoplasty: a novel nonsurgical approach for myocardial cell transplantation. J Am Coll Cardiol 2003, 41:1964-1971.

7. Haffner SM, Lehto S, Ronnemaa T, Pyorala K, Laakso M: Mortality from coronary heart disease in subjects with type 2 diabetes and in nondiabetic subjects with and without prior myocardial infarction. $N$ Engl J Med 1998, 339:229-234.

8. Jiménez-Quevedo P, Silva GV, Sanz-Ruiz R, Oliveira EM, Fernandes MR, Angeli F, Willerson JT, Dohmann HF, Perin EC: Diabetic and nondiabetic patients respond differently to transendocardial injection of bone marrow mononuclear cells: findings from prospective clinical trials in "no-option" patients. Rev Esp Cardiol 2008, 61:635-639.

9. Vöö S, Dunaeva M, Eggermann J, Stadler N, Waltenberger J: Diabetes mellitus impairs CD133+ progenitor cell function after myocardial infarction. J Intern Med 2009, 265:238-249.

10. Meerwaldt R, Links T, Zeebregts C, Tio R, Hillebrands JL, Smit A: The clinical relevance of assessing advanced glycation endproducts accumulation in diabetes. Cardiovascular Diabetology 2008, 7:29.

11. Pu LJ, Lu L, Xu XW, Zhang RY, Zhang Q, Zhang JS, Hu J, Yang ZK, Ding FH, Chen QJ, Lou S, Shen J, Fang DH, Shen WF: Value of serum glycated albumin and high-sensitivity C-reactive protein levels in the prediction of presence of coronary artery disease in patients with type 2 diabetes. Cardiovascular Diabetology 2006, 5:27.

12. Kume S, Kato S, Yamagishi S, Inagaki Y, Ueda S, Arima N, Okawa T, Kojiro M, Nagata K: Advanced glycation end-products attenuate human mesenchymal stem cells and prevent cognate differentiation into adipose tissue, cartilage, and bone. J Bone Miner Res 2005, 20:1647-58.

13. Pittenger MF, Mackay AM, Beck SC, Jaiswal RK, Douglas R, Mosca JD, Moorman MA, Simonetti DW, Craig S, Marshak DR: Multilineage potential of adult human mesenchymal stem cells. Science 1999, 284:143-147.

14. Nagaya N, Kangawa K, Itoh T, Iwase T, Murakami S, Miyahara Y, Fujii T, Uematsu M, Ohgushi H, Yamagishi M, Tokudome T, Mori H, Miyatake K, Kitamura S: Transplantation of mesenchymal stem cells improves cardiac function in a rat model of dilated cardiomyopathy. Circulation 2005, 112:1128-1135.

15. Mosmann T: Rapid colorimetric assay for cellular growth and survival: application to proliferation and cytotoxicity assays. J Immunol Methods 1983, 65:55-63.

16. Yamagishi S, Edelstein D, Du XL, Kaneda Y, Guzman M, Brownlee M: Leptin induces mitochondrial superoxide production and monocyte chemoattractant protein-1 expression in aortic endothelial cells by increasing fatty acid oxidation via protein kinase A. J Biol Chem 2001, 276:25096-25100.

17. Faber-Elman A, Solomon A, Abraham JA, Marikovsky M, Schwartz M: Involvement of woundassociated factors in rat brain astrocyte migratory response to axonal injury: In vitro simulation. J Clin Invest 1996, 97:162-171.

18. Wright GW, Simon RM: A random variance model for detection of differential gene expression in small microarray experiments. Bioinformatics 2003, 19:2448-2455.

19. Yang $H$, Crawford N, Lukes L, Finney R, Lancaster M, Hunter KW: Metastasis predictive signature profiles pre-exist in normal tissues. Clin Exp Metastasis 2005, 22:593-603.

20. Clarke R, Ressom HW, Wang A, Xuan J, Liu MC, Gehan EA, Wang Y: The properties of high-dimensional data spaces: implications for exploring gene and protein expression data. Nat Rev Cancer 2008, 8:37-49. 
21. Pujana MA, Han JD, Starita LM, Stevens KN, Tewari M, Ahn JS, Rennert G, Moreno V, Kirchhoff T, Gold B, Assmann V, Elshamy WM, Rual JF, Levine D, Rozek LS, Gelman RS, Gunsalus KC, Greenberg RA, Sobhian B, Bertin N, Venkatesan K, Ayivi-Guedehoussou N, Solé X, Hernández P, Lázaro C, Nathanson KL, Weber BL, Cusick ME, Hill DE, Offit K, Livingston DM, Gruber SB, Parvin JD, Vidal M: Network modeling links breast cancer susceptibility and centrosome dysfunction. Nat Genet 2007, 39:1338-1349.

22. Barabási AL, Oltvai ZN: Network biology: understanding the cell's functional organization. Nat Rev Genet 2004, 5:101-113.

23. Prieto C, Risueño A, Fontanillo C, De las Rivas J: Human gene coexpression landscape: confident network derived from tissue transcriptomic profiles. PLoS One 2008, 3:e3911.

24. Stern D, Yan SD, Yan SF, Schmidt AM: Receptor for advanced glycation endproducts: a multiligand receptor magnifying cell stress in diverse pathologic settings. Adv Drug Deliv Rev 2002, 54:1615-1625.

25. Taguchi A, Blood DC, del Toro G, Canet A, Lee DC, Qu W, Tanji N, Lu Y, Lalla E, Fu C, Hofmann MA, Kislinger T, Ingram M, Lu A, Tanaka H, Hori O, Ogawa S, Stern DM, Schmidt AM: Blockade of RAGE-amphoterin signalling suppresses tumour growth and metastases. Nature 2000, 405:354-360.

26. Liu J, Zhao S, Tang J, Li Z, Zhong T, Liu Y, Chen D, Zhao M, Li Y, Gong X,

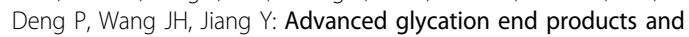
lipopolysaccharide synergistically stimulate proinflammatory cytokine/ chemokine production in endothelial cells via activation of both mitogen-activated protein kinases and nuclear factor-kappaB. FEBS J 2009, 16:4598-606.

27. Fukami K, Ueda S, Yamagishi S, Kato S, Inagaki Y, Takeuchi M, Motomiya Y, Bucala R, lida S, Tamaki K, Imaizumi T, Cooper ME, Okuda S: AGEs activate mesangial TGF- $\beta$ - Smad signaling via an angiotensin II-type I receptor interaction. Kidney Int 2004, 66:2137-2147.

28. Wautier MP, Chappey O, Corda S, Stern DM, Schmidt AM, Wautier JL: Activation of NADPH oxidase by AGE links oxidant stress to altered gene expression via RAGE. Am J Physiol Endocrinol Metab 2001, 280: E685-E694.

29. Vahtola E, Louhelainen M, Forstén $H$, Merasto S, Raivio J, Kaheinen $P$, Kytö V, Tikkanen I, Levijoki J, Mervaala E: Sirtuin1-p53, forkhead box O3a, p38 and post-infarct cardiac remodeling in the spontaneously diabetic Goto-Kakizaki rat. Cardiovasc Diabetol 2010, 27(9):5.

30. Lee GT, Kwon SJ, Lee JH, Jeon SS, Jang KT, Choi HY, Lee HM, Kim WJ, Kim SJ, Kim IY: Induction of interleukin-6 expression by bone morphogenetic protein- 6 in macrophages requires both Smad and P38 signaling pathways. J Biol Chem 2010.

31. Yamaoka-Tojo M, Tojo T, Takahira N, Matsunaga A, Aoyama N, Masuda T, Izumi T: Elevated circulating levels of an incretin hormone, glucagon-like peptide-1, are associated with metabolic components in high-risk patients with cardiovascular disease. Cardiovasc Diabetol 2010, 14(9):17.

32. Nakamura K, Yamagishi S, Adachi H, Matsui T, Kurita-Nakamura Y, Takeuchi $M$, Inoue $H$, Imaizumi T: Circulating advanced glycation end products (AGEs) and soluble form of receptor for AGEs (sRAGE) are independent determinants of serum monocyte chemoattractant protein1 (MCP-1) levels in patients with type 2 diabetes. Diabetes Metab Res Rev 2008, 24:109-114.

33. Piemonti L, Calori G, Lattuada G, Mercalli A, Ragogna F, Garancini MP, Ruotolo G, Luzi L, Perseghin G: Association between plasma monocyte chemoattractant protein-1 concentration and cardiovascular disease mortality in middle-aged diabetic and nondiabetic individuals. Diabetes Care 2009, 32:2105-2110.

34. Castoldi G, Galimberti S, Riva C, Papagna R, Querci F, Casati M, Zerbini G, Caccianiga G, Ferrarese C, Baldoni M, Valsecchi MG, Stella A: Association between serum values of $C$-reactive protein and cytokine production in whole blood of patients with type 2 diabetes. Clin Sci (Lond) 2007, 113:103-108.

35. Shehadeh N, Pollack S, Wildbaum G, Zohar Y, Shafat I, Makhoul R, Daod E, Hakim F, Perlman R, Karin N: Selective autoantibody production against CCL3 is associated with human type 1 diabetes mellitus and serves as a novel biomarker for its diagnosis. J Immunol 2009, 182:8104-8109.

36. Cameron MJ, Arreaza GA, Grattan M, Meagher C, Sharif S, Burdick MD, Strieter RM, Cook DN, Delovitch TL: Differential expression of CC chemokines and the CCR5 receptor in the pancreas is associated with progression to type I diabetes. J Immunol 2000, 165:1102-1110.
37. Yang J, Park Y, Zhang H, Gao X, Wilson E, Zimmer W, Abbott L, Zhang C: Role of MCP-1 in tumor necrosis factor-alpha-induced endothelial dysfunction in type 2 diabetic mice. Am J Physiol Heart Circ Physiol 2009, 297:H1208-1216.

38. Niu J, Kolattukudy PE: Role of MCP-1 in cardiovascular disease: molecular mechanisms and clinical implications. Clin Sci (Lond) 2009, 117:95-109.

39. Maedler K, Dharmadhikari G, Schumann DM, Størling J: Interleukin-1 beta targeted therapy for type 2 diabetes. Expert Opin Biol Ther 2009, 9:1177-1188.

40. Konishi H, Nakatsuka M, Chekir C, Noguchi S, Kamada Y, Sasaki A, Hiramatsu Y: Advanced glycation end products induce secretion of chemokines and apoptosis in human first trimester trophoblasts. Hum Reprod 2004, 19:2156-2162.

41. Li JT, Hou FF, Guo ZJ, Shan YX, Zhang X, Liu ZQ: Advanced glycation end products upregulate $C$-reactive protein synthesis by human hepatocytes through stimulation of monocyte IL- 6 and IL-1 beta production. Scand J Immunol 2007, 66:555-562.

42. Zhang F, Tsai S, Kato K, Yamanouchi D, Wang C, Rafii S, Liu B, Kent KC: Transforming growth factor-beta promotes recruitment of bone marrow cells and bone marrow-derived mesenchymal stem cells through stimulation of MCP-1 production in vascular smooth muscle cells. $J$ Biol Chem 2009, 284:17564-17574.

43. Belema-Bedada F, Uchida S, Martire A, Kostin S, Braun T: Efficient homing of multipotent adult mesenchymal stem cells depends on FROUNTmediated clustering of CCR2. Cell Stem Cell 2008, 2:66-75.

44. Stich S, Loch A, Leinhase I, Neumann K, Kaps C, Sittinger M, Ringe J: Human periosteum-derived progenitor cells express distinct chemokine receptors and migrate upon stimulation with CCL2, CCL25, CXCL8, CXCL12, and CXCL13. Eur J Cell Biol 2008, 87:365-376.

45. Schmal H, Niemeyer P, Roesslein M, Hartl D, Loop T, Südkamp NP, Stark GB, Mehlhorn AT: Comparison of cellular functionality of human mesenchymal stromal cells and PBMC. Cytotherapy 2007, 9:69-79.

46. Glossop JR, Cartmell SH: Effect of fluid flow-induced shear stress on human mesenchymal stem cells: differential gene expression of IL1B and MAP K 38 in MAPK signaling. Gene Expr Patterns 2009, 9:381-388.

\section{doi:10.1186/1475-2840-9-66}

Cite this article as: Yang et al:: Advanced glycation end products induce chemokine/cytokine production via activation of p38 pathway and inhibit proliferation and migration of bone marrow mesenchymal stem cells. Cardiovascular Diabetology 2010 9:66.

\section{Submit your next manuscript to BioMed Central and take full advantage of:}

- Convenient online submission

- Thorough peer review

- No space constraints or color figure charges

- Immediate publication on acceptance

- Inclusion in PubMed, CAS, Scopus and Google Scholar

- Research which is freely available for redistribution 